\title{
Research on New Energy High-rate Dissipation Strategy under the Background of Renewable Energy Quota System
}

\author{
Xiao Daqiang ${ }^{1}$, Liu Dunnan ${ }^{2}$,Yang Ruixing ${ }^{3}$,Wang Xiongfei ${ }^{2}$ \\ ${ }^{1}$ Central China Branch of State Grid Corporation, Wuhan 430077, China \\ ${ }^{2}$ North China Electric Power University,Beijing,102206, China \\ ${ }^{3}$ China Resources Power Holdings Co., Ltd. Huazhong Company, Wuhan,430000, China
}

\begin{abstract}
In recent years, China's new energy has developed rapidly, and at the same time there have been serious problems of abandoning wind and abandoning light. In order to better solve the problem of new energy consumption, China officially implemented the renewable energy quota system in January 2019. Therefore, based on the current situation of new energy consumption in China, this paper first analyzes the impact of renewable energy quota policy from two aspects: capacity efficiency and grid connectivity effect, and then based on tapping local energy potential, accepting trans-regional power transmission, and optimizing outside the region. The corresponding new energy consumption strategy is proposed in the power transmission curve. Finally, based on the time series production simulation model, an empirical analysis is made on the consumption situation of a certain provincial power grid under different strategies in 2020. This paper provides a reference for promoting the proportion of new energy consumption in China.
\end{abstract}

\section{Introduction}

In recent years, issues such as the environment and resources have been widely regarded as important factors affecting the development of the entire human society. New energy, represented by wind power generation and photovoltaic power generation, is a clean, efficient and renewable product,and an effective way to solve energy shortage and environmental friendly development problems $^{[1-2]}$.

Since 2011, China has continuously explored the implementation of the renewable energy quota system. The literature ${ }^{[3-5]}$ verifies the feasibility of implementing the quota trading system in China, and proposes the preliminary framework and countermeasures for the implementation of the quota system. Literature ${ }^{[6-9]}$ studied the operational mechanism and management mechanism of renewable energy quotas. The existing research on the quota system focuses on the feasibility and institutional arrangements of the implementation of the quota system $^{[10-11]}$, and lacks a specific analysis of the impact of the policy after the implementation of the quota systemAt present, the research on new energy consumption strategies mainly focuses on power supply regulation, grid interconnection and power substitution ${ }^{[12]}$, and lacks analysis of time series production simulation.

This paper first studies the allocation of quota indicators under China's renewable energy quota policy. From the two aspects of capacity effect and grid connectivity effect, this paper analyzes the impact of renewable energy quota policy on new energy industry development and grid interoperability level, and then proposes corresponding The new energy consumption strategy and a comprehensive strategy to consider the process of optimizing the out-of-area transmission curve. Finally, an empirical analysis of the consumption situation of a provincial power grid before and after the new energy consumption strategy in 2020 is conducted, which is of guiding significance for promoting the sustainable development of China's non-water renewable energy power generation

\section{Analysis of New Energy Consumption Strategy under the Renewable Energy Quota Target}

\subsection{Analysis of new energy consumption strategies}

(1) By enhancing the local new energy development capability and technology level, the installed capacity and grid capacity can be increased. At present, new energy development in many provinces in China is still in the initial stage of development, and there is still room for improvement in technical level and cost competitiveness. Therefore, provinces can use local weather geography and other resources according to local conditions, and combine their own conditions to develop more suitable energy types and fully tap the potential of their new energy utilization.

(2) Play the role of trans-provincial trans-regional transmission channels and make rational use of calls

* Corresponding author: Wang Xiongfei:13051611911@163.com 
outside the zone. Since the development of new energy sources such as wind power and photovoltaics will be constrained by natural resource conditions, under certain technical conditions, the available capacity of local new energy in many provinces is limited. In the case of full utilization of local new energy, provinces that have not yet reached the target of consumption quotas may consider to absorb surplus power outside the province through new energy transmission channels across provinces and regions.

(3) By optimizing the transmission curve, the win-win situation of new energy consumption level and quality level can be promoted. The curve optimization process of adding the power transmission line in the strategy can effectively improve the new energy consumption of the receiving power grid and obtain the maximum energy utilization efficiency of the entire interconnected area.

\subsection{Time series production simulation model}

The power system time series production simulation is the basic method for the new energy consumption analysis such as grid wind power. The simulation operation optimization objective function is as follows

$$
\min F=\min \sum_{t=1}^{T}\left(F_{R, t}+F_{\text {LOSS }, t}\right)
$$

Where: $F_{R, \mathrm{t}}$ is t-time system energy consumption cost; $F_{\text {LOSS, } t}$ is the penalty for the system loss of load for the $\mathrm{t}$ period; $\mathrm{T}$ is the number of scheduling periods.

The power generation cost of a thermal power unit is composed of coal consumption cost and start-up cost., Its expression is

$$
F_{R, \mathrm{t}}=\sum_{i=1}^{N}\left[u_{i, t}\left(a_{i} P_{i, t}^{2}+b_{i} P_{i, t}+c_{i}\right)+S_{i, t}\right]
$$

Where: $N$ is the number of thermal power units; $u_{i, t}$ is the operating state of the thermal motor unit $i$ during the $t$ period; $a_{i} 、 b_{i}, c_{i}$ is the cost factor of thermal power unit $i ; P_{i, t}$ is the output of the thermal power unit $i$ during the $t$ period; $S_{i, t}$ is the start-stop cost of the thermal power unit $i$ during the $t$ period. The system load penalty fee is

$$
F_{\text {LOSS }, t}=C_{\text {LOSS }} E_{\text {LOSS }, t}
$$

where: $C_{\text {LOSS }}$ is the unit loss of load penalty fee; $E_{L O S S, t}$ is the expected value of the system's unloaded power during the $\mathrm{t}$ period. The constraint is:

(1) System power balance constraints

$$
\sum_{i=1}^{N} P_{i, t}+\sum_{i=1}^{N_{S}} P_{S, i, t}+\sum_{i=1}^{N_{W}} P_{W, i, t}+\sum_{i=1}^{N_{\text {line }}} P_{\text {line }, i, t}=P_{L, t}
$$

where: $P_{S, i, t}$ and $P_{W, i, t}$ are the power generation output of the photovoltaic power station and the wind farm $i$ in the t-time period, respectively; $P_{\text {line, } i, t}$ is the transmission power of the time zone contact line $i$, the positive value is sent, and the negative value is sent; $P_{L, t}$ is the system load of the time period; $N_{S}$ and $N_{W}$ are the number of photovoltaic power plants and wind farms, respectively; $N_{\text {line }}$ is the number of contact lines.

(2) Conventional thermal power unit related constraints, including the upper and lower limits of the output force, the start and stop constraints, and so on.

(3) New energy power generation output operation constraints

$$
\begin{aligned}
& 0 \leq P_{W, i, t} \leq P_{W, i, \max } \\
& 0 \leq P_{S, i, t} \leq P_{S, i, \max }
\end{aligned}
$$

where: $P_{W, i, \max }$ and $P_{S, i, \max }$ are the theoretical maximum power of wind farm $i$ and photovoltaic power station $i$, respectively.

(4) Cross-regional tie line constraints

$$
\begin{gathered}
P_{\text {line }, i, \min } \leq P_{\text {line }, i, t} \leq P_{\text {line }, i, \max } \\
\sum_{t=1}^{T} P_{\text {line }, i, t} \Delta T=E_{\text {line }, i}
\end{gathered}
$$

where : $P$ line, $i, \min$ and $P$ line, $i, \max$ are the minimum and maximum power limits of tie line $i$, respectively; Eline, $i$ is the protocol power of the contact line $\mathrm{i}$ in the time period $\mathrm{T}$.

\section{Empirical analysis}

\subsection{Basic scenario}

Based on the power planning level of a province in 2020 , regardless of biomass power generation (small proportion), the consumption of new energy in the system under the basic scenario is calculated. The installed capacity of the power grid in 2020 is about 33.86 million $\mathrm{kW}, 17.73$ million $\mathrm{kW}, 1.2$ million $\mathrm{kW}, 5$ million $\mathrm{kW}, 2$ million $\mathrm{kW}$, and the total installed capacity is 59.796 million $\mathrm{kW}$. The simulated consumption results are: the whole society uses 18 billion $\mathrm{kWh}$ of electricity, the new energy generation is 11.493 billion $\mathrm{kWh}$, the new energy consumption ratio is $5.74 \%$, the abandoned wind rate is $2.26 \%$, and the light rejection rate is $0.16 \%$. According to the "Guidance Opinions", the non-water renewable energy quota targets of the provincial power grid are considered to be $5 \%, 7 \%, 10 \%$ and $13 \%$ respectively. According to the production simulation results, the proportion of local new energy consumption in the basic scenario is $5.74 \%$, which can meet the requirements of $5 \%$ of the consumption of electricity, but there is a certain gap from other targets, so it can be combined with the new energy consumption under different consumption strategies. Situation, analyze the effectiveness of each strategy. 


\subsection{Increasing the scene analysis of outbound calls}

Assume that the province's new energy resources have been fully exploited and utilized under the basic planning level. According to the province's "13th Five-Year" power plan, a trans-regional transport channel with a capacity of 8 million $\mathrm{kW}$ will be put into operation in 2020. Out-ofarea calls to achieve the 2020 renewable energy power quota target. Therefore, the new energy consumption of the provincial power grid under different utilization hours of the DC channel can be analyzed. The transmission data of the channel is shown in Table 1, and the results of the consumption are shown in Table 2. Thus, with the gradual increase of the outward power supply, the dual objectives of eliminating the landscape power and quality can be achieved under the $7 \%$ quota requirement. However, when the quota indicator is raised to $10 \%$ or even $13 \%$, if only consider increasing the power supply outside the zone to meet the power consumption target, the abandoned wind rate and the light rejection rate of the power grid will seriously exceed the standard. Therefore, further consideration can be given to increasing the proportion of new energy transmission in the inter-zone channel. At present, due to technical limitations, the channel's new energy ratio can reach up to $75 \%$. At this time, the inter-area channel transmission data that meets the $10 \%$ renewable energy consumption quota is shown in scenario 3 , and the abandoned light rate is up to standard. There is a certain limit of the wind rate, and it can be considered to analyze the consumption method of the optimized tie line power transmission. In scenario 4 , the new energy abandonment rate is seriously exceeded, and the single strategy of increasing the outbound call is not applicable to the indicator level.

Table 1 Cross-area DC channel transmission data

\begin{tabular}{|l|l|l|l|l|l|}
\hline $\begin{array}{l}\text { Scen } \\
\text { es }\end{array}$ & $\begin{array}{l}\text { Channe } \\
\text { utilizati } \\
\text { on } \\
\text { hours/h }\end{array}$ & $\begin{array}{l}\text { Conveying } \\
\text { electricity/ } \\
100 \text { million } \\
\mathrm{kWh}\end{array}$ & $\begin{array}{l}\text { Fixed } \\
\text { powe } \\
\mathrm{r} \\
/ 10,0 \\
00 \\
\mathrm{~kW}\end{array}$ & $\begin{array}{l}\text { New } \\
\text { ener } \\
\text { gy } \\
\text { ratio } \\
/ \%\end{array}$ & $\begin{array}{l}\text { Conveyi } \\
\text { ng new } \\
\text { energy } \\
\text { power/1 } \\
00 \\
\text { million } \\
\mathrm{kWh}\end{array}$ \\
\hline $\begin{array}{l}\text { scene } \\
1\end{array}$ & 750 & 60 & 68.36 & 30 & 18 \\
\hline $\begin{array}{l}\text { scene } \\
2\end{array}$ & 1100 & 88 & 99.13 & 30 & 26.4 \\
\hline $\begin{array}{l}\text { scene } \\
3\end{array}$ & 1500 & 120 & $\begin{array}{l}136.7 \\
2\end{array}$ & 75 & 90 \\
\hline $\begin{array}{l}\text { scene } \\
4\end{array}$ & 2625 & 210 & $\begin{array}{l}239.2 \\
6\end{array}$ & 75 & 157.5 \\
\hline
\end{tabular}

Table 2 Simulation results of different scenarios of a provincial power grid

\begin{tabular}{|c|c|c|c|c|c|}
\hline $\begin{array}{l}\text { Sce } \\
\text { nes }\end{array}$ & $\begin{array}{l}\text { Local new } \\
\text { energy } \\
\text { consumpti } \\
\text { on/100 } \\
\text { million } \\
\text { kWh }\end{array}$ & $\begin{array}{l}\text { Input } \\
\text { new } \\
\text { energy/ } \\
100 \\
\text { million } \\
\text { kWh } \\
\text { outside } \\
\text { the }\end{array}$ & $\begin{array}{l}\text { New } \\
\text { energy } \\
\text { consum } \\
\text { ption } \\
\text { ratio /\% }\end{array}$ & $\begin{array}{l}\text { Aband } \\
\text { oned } \\
\text { wind } \\
\text { rate } / \%\end{array}$ & $\begin{array}{l}\text { Light } \\
\text { reject } \\
\text { ion } \\
\text { rate } \\
1 \%\end{array}$ \\
\hline
\end{tabular}

\begin{tabular}{|l|l|l|l|l|l|}
\hline & & zone & & & \\
\hline $\begin{array}{l}\text { Basi } \\
\text { c } \\
\text { scen } \\
\text { e }\end{array}$ & 114.93 & 0 & 5.74 & 2.26 & 0.16 \\
\hline $\begin{array}{l}\text { scen } \\
\text { e 1 }\end{array}$ & 113.72 & 18.0 & 6.65 & 3.38 & 0.63 \\
\hline $\begin{array}{l}\text { scen } \\
\text { e 2 }\end{array}$ & 111.85 & 26.4 & 7.00 & 5.00 & 1.91 \\
\hline $\begin{array}{l}\text { scen } \\
\text { e 3 }\end{array}$ & 108.59 & 90.0 & 10.03 & 7.89 & 4.12 \\
\hline $\begin{array}{l}\text { scen } \\
\text { e 4 }\end{array}$ & 101.00 & 157.5 & 13.06 & 14.34 & 10.61 \\
\hline
\end{tabular}

\subsection{Optimizing the scene analysis of the power transmission curve outside the zone}

For the optimization analysis of scenario 3 in Section 4.3, consider the 3.3-line tie line transmission curve optimization process, and analyze the historical annual load characteristic curve of the province. The province's power grid summer July-August and autumn-winter November-1 The monthly load demand is large, and the load demand is small from May to June in spring.

Then, considering the peak period of photovoltaic power generation at the cross-channel channel and the power curve step constraint and power adjustment times of the DC channel, the power transmission curve of each day of the DC channel can be optimized, combined with the season of the above analysis. With the transfer characteristics, the power transmission curve as shown in Fig. 2 can be obtained.

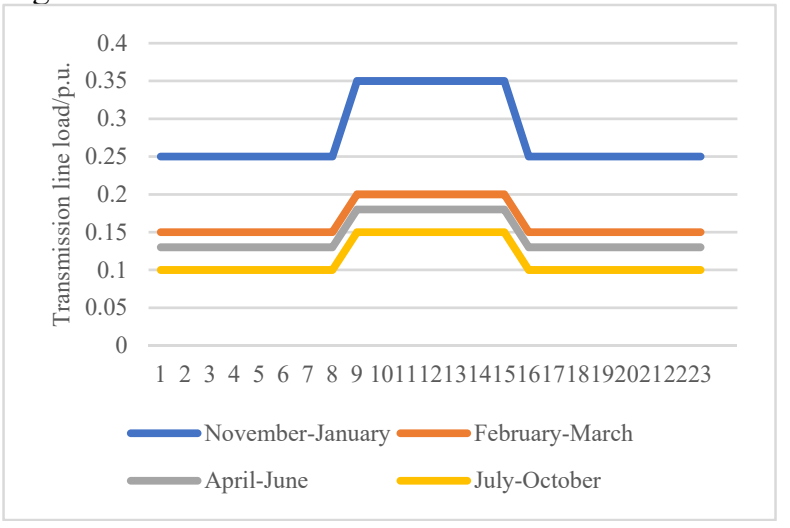

Figure2 Optimized cross-region channel power transmission curve

The optimized transmission curve is substituted into the model for production simulation, and the results of the new energy consumption of a certain provincial power grid in 2020 are shown in Table 3. The comparison shows that the optimized transmission curve effectively improves the abandonment and abandonment of the provincial power grid, improves the new energy consumption of the grid, and eliminates the non-regional grid through the optimized scheduling process of the tie line. Water renewable energy and improving the 
economics of power grid operation have brought significant benefits.

Table 3 Simulation results of optimized power transmission curve under limiting effec

\begin{tabular}{|l|l|l|l|l|l|}
\hline Scenes & $\begin{array}{l}\text { Local } \\
\text { new } \\
\text { energy } \\
\text { consum } \\
\text { ption } \\
/ 100 \\
\text { million } \\
\mathrm{kWh}\end{array}$ & $\begin{array}{l}\text { Input } \\
\text { new } \\
\text { energy } \\
/ 100 \\
\text { million } \\
\mathrm{kWh} \\
\text { outside } \\
\text { the } \\
\text { zone }\end{array}$ & $\begin{array}{l}\text { New } \\
\text { energy } \\
\text { consum } \\
\text { ption } \\
\text { ratio } / \%\end{array}$ & $\begin{array}{l}\text { Aband } \\
\text { oned } \\
\text { wind } \\
\text { rate } / \%\end{array}$ & $\begin{array}{l}\text { Light } \\
\text { reject } \\
\text { ion } \\
\text { rate } \\
/ \%\end{array}$ \\
\hline $\begin{array}{l}\text { Fixed } \\
\text { power } \\
\text { transmi } \\
\text { ssion }\end{array}$ & 108.59 & 90 & 10 & 7.89 & 4.12 \\
\hline $\begin{array}{l}\text { Optimiz } \\
\text { ed } \\
\text { power } \\
\text { transmi } \\
\text { ssion } \\
\text { curve }\end{array}$ & 112.21 & 90 & 10.21 & 4.72 & 1.55 \\
\hline
\end{tabular}

\section{Conclusion}

Based on the policy background of the development and utilization of renewable energy, this paper first studies the distribution of indicators in different regions under the quota policy, and clarifies that the establishment of renewable energy consumption quota indicators will affect the level of new energy development and consumption in various regions. situation.

Secondly, the theory of policy effects can be seen that the implementation of renewable energy quota policies can effectively promote the increase of new energy installed capacity, and strengthen the level of grid interconnection and expand the scope of new energy allocation; however, a high proportion of new energy sources may limit consumption. Therefore, when proposing the corresponding new energy consumption strategy, we can consider adding the tie line power optimization process, in order to realize the new energy consumption strategy of sending and receiving doubleend win-win.

Finally, based on the time series production simulation model, taking a provincial power grid as an example, it is verified that the new energy installed capacity and the use of out-of-zone calls and other consumption strategies to respond to different quota policies.

\section{Acknowledgement}

Central China Branch of State Grid Corporation Management Consulting Project (Research on the Path of Market Mechanism Promoting New Energy Development under the Trend of Photovoltaic Subsidies)

\section{References}

1. Pavaloaia L, Georgescu I, Georgescu M. The
System of Green Certificates - Promoter of Energy from Renewable Resources [J]. Procedia - Social and Behavioral Sciences, 2015, 188:206-213

2. $\mathrm{Hu}$ Zechun, Luo Haocheng .Research Status and Prospects of Automatic Generation Control in the Background of Large-scale Renewable Energy Access[J].Automation of Electric Power Systems,2018,42(08):2-15.

3. Liu Ruifeng, Liu Weigang, Zhang Wen, Liu Jing, Chen Tianen northwest quota system based on renewable energy cross inter-provincial electricity trade economic evaluation $[\mathrm{J}]$ grid and clean energy, 2014,30 (01): 59-63.

4. Wang L, Endrud N E, Turns S R, et al. A Study of the Influence of Oxygen Index on Soot, Radiation, and Emission Characteristics of Turbulent Jet Flames[J]. Combustion Science \& Technology, 2002, 174(8):45-72.

5. Li Xinglong. Interpretation and Suggestion of Renewable Energy Power Quota System[J].Science and Technology Economics Guide, 2019,27(04):104105.

6. Ren Dongming. Discussion on China's Renewable Energy Quota System and Implementation Countermeasures[J]. Automation of Electric Power Systems, 2011, 35(22): 25-28.

7. Dong Litong. Research on the implementation of renewable energy quota system in China under the electricity market [D]. North China Electric Power University (Beijing), 2006.

8. Zhong Haiwang, Xia Qing, Ding Maosheng, et al. A new model for optimizing the capacity of new energy consumption by DC link operation mode [J]. Power System Technology 2015, 39(3): 36-42.

9. State Energy Administration. Notice on Establishing the Relevant Requirements for the Assessment System for Non-water Renewable Energy Power Generation Quota for Coal-fired Thermal Power Units (Draft for Comment) [Z]. 2016.

10. ZHANG Y, ZHAO X, ZUO Y, et al. The development of the renewable energy power industry under feed-in tariff and renewable portfolio standard: A case study of China's photovoltaic power industry[J]. Sustainability,2017,9(4):532

11. Yan Jingwei. Research on multi-regional coordinated consumption strategy for new energy [D]. North China Electric Power University, 2018.

12. Luo Chengxian. Renewable Energy Quota System in California and Its Enlightenment to China [J]. Chinese and Foreign Energy, 2016, 21(12):19-26. 